\title{
Diverging experiences of work and social networks abroad: Highly-skilled British migrants in Singapore, Vancouver and Boston
}

\author{
William S. Harvey and Jonathan V. Beaverstock
}

\begin{abstract}
This chapter analyses the work and social networks of British migrants working in Singapore, Vancouver and Boston. We show that their experiences of working and networking with other migrants varied markedly, despite the fact that they had similar education, professional and social backgrounds. This is important because when priorities of work and socialization abroad are not uniform, institutional approaches to engaging with these groups needs to be tailored to their needs. We provide insights into how governments and organizations may more effectively attract, retain and engage with highly-skilled migrants.
\end{abstract}

\section{Introduction}

This chapter introduces some of the contemporary literature on highly-skilled migration across a range of social science disciplines. We draw-upon evidence from four separate research projects on highly-skilled migrants working in Singapore, Vancouver and Boston. Despite the fact that these workers have similar levels of education, skills, training and backgrounds, we show that they vary significantly in their experiences of migration, work and social networks in the different host countries. Theoretically, this is important because we show that highly-skilled migrants are far from homogeneous in their experiences of migration and integration, and significantly, that they produce and reproduce what Smith $(1999,12-124)$ refers to as, "transnational social space" within the city. The idea of exclusive migrant or expatriate spatialities within cities are not new (see, King, 1976). But, what we show is that the production of expatiates' social networks in 
particular transnational spaces within the city, in close-proximity to the home, workplace and downtown area, creates a distinctive agency of place, which are crucial territories for migrant social network formation and practice, as also argued by Ley (2004) and Waters (2007). As Beaverstock $(2011,712)$ noted, “...an important social cultural trait of the expatriate is the tendency to be dotted around the city in distinctive separated, transnational spaces". Practically, we argue that the skills of these groups have generally been recognised locally in the host country, but there are major untapped international opportunities for British organisations and its government to more actively engage with them for business networking, foreign direct investment and talent mobility purposes. We also argue, importantly, that there remains a dearth of research which understands the, “translocality" (Smith, 1999, 121) or agency of place of highly-skilled migrants' social networks in the city, particularly in an age of Castells' (2000) The Network Society.

The chapter is organised into six main parts. In part one we briefly discuss the major organisational mechanisms which creates the condition for the demand of highlyskilled migrants in the world economy, drawing on writers from across the social sciences and International Human Resource Management. We then move on to reviewing the current approaches to highly-skilled international migration and specifically the role of nation states in attracting such workers to 'win the war' for global talent. Part three focuses on the agency of migrant networks, both social and business, and formal and informal, in supporting highly-skilled migrants in new host countries. Importantly, we also build upon Smith's (1999) ideas of transnational social spaces to illustrate the significance of the agency of place in the formation and sustainability of migrant social networks. Parts four and five introduces and reports the major findings from the four case study surveys of the role of networks in integrating British highly-skilled migrants in Singapore, Vancouver and Boston. Finally, in part six we report several conclusions and 
highlight the contribution of our research to extant debates on highly-skilled international labour migration and the production of transnational social spaces, the agency of place, in a rapidly globalizing world and city-system.

\section{Organisational corporate highly-skilled migration}

A significant driver for the demand of highly-skilled international migrants, of all nationalities, are those firms which engage in international production outside of their home country. The multinational corporation, across primary, secondary and tertiary sectors, is one of the key actors in the world economy that facilitates the migration of highly-skilled persons across national borders. By 2014, it has been estimated that there could be upward of 50 million expatriates worldwide. ${ }^{1}$ Since the establishment of the US and European multinational corporations from the 1920s onwards, such firms have engaged in transferring highly-skilled labour to international locations. The purpose of this has been to manage and fill vacancies in new and established subsidiaries, offices and other foreign investments (e.g. oil fields, agricultural plantations, mineral mining). In the modern day, multinational corporations, and also small and medium sized firms, continue to seek highly-skilled labour of all nationalities from outside of their national labour markets in order to engage in the production of goods and services in a highly competitive globalised world. Multinational firms have effectively become, 'transnational communities' (Morgan, 2001) and these organisations provide essential places for migrants to successfully build and sustain social and business networks, as discussed later. From the late 1970s, scholars in business and management have examined these processes in a newly formulated discipline, International Human Resource Management (Bach, 2011; Tung, 1988). Human geographers and migration specialists have sought to theorise and measure such migration flows as 'transient' highly-skilled international migration (Appleyard, 1991; Beaverstock, 1996; 2004; Cormode, 1994; Findlay, 1990; Salt and 
Findlay, 1989; Salt, 1988). Such studies also encompassed the strategic role of the firm, an individual's career path aspirations and State immigration regulatory change. But, also contextualised such migration in the rapid structural changes occurring in the world economy and resultant spatial re-organisation and restructuring of production deindustrialisation and the rise of the service sector. Significant territorial changes include, the strategic dominance of world cities and 'clusters' of high-value production and innovation, like Silicon Valley (Castells, 1989; Sassen, 1991; Saxenian, 2006), and more recently the relative opening-up of the former Communist countries, including China, and the neo-liberalisation of the formerly so-called, 'First World' economies.

Today, the international migration and mobility of highly-skilled labour within and between the global internal labours of multinational corporations is a normalised process for organising work on a transnational scale (Beaverstock, 2007). The foundational text by Edstrom and Galbraith $(1977,252-253)$ noted that managers were transferred within the international internal labour markets of multinational firms, across borders, for three main reasons:

First, many transfers are made to fill positions when qualified local individuals are not available or easily trained ... The second motive for transfer is to develop managers for positions of responsibility in organizations doing significant amounts of international business; that is even if there were qualified local individuals available ... the third reason for transfer was ... to use transfer of organizational development ... as a means of modifying and sustaining its structure and decision making processes.

This landmark paper remains the benchmark for theorising firms' international human resource management systems. In essence, and drawing upon the work of Sparrow et al. (2004), firms trigger the demand for a highly-skilled migrant, or an 'expatriate' (known as an inter-company transfer) because such workers are required to: plug local vacancies; exchange and transfer codified and tacit knowledge and expertise; train and manage the local labour force and other assets; provide leadership and ensure 
that there is best practice; and to ensure that the corporate strategy of the firm is being adhered to in terms of production, quality control and strategy. Sparrow et al. (2004) also acknowledge that highly-skilled international migration stimulated by firms is an essential strategy for developing the career paths of their employees and for establishing an international cadre of global staff for the organisation. Several examples of multinational corporations generating highly-skilled migration has been examined in detail across a number of sectors, including accounting (Beaverstock, 2007), aerospace and extraction (Millar and Salt, 2008), legal services (Beaverstock, 2004) and pharmaceuticals and biotechnology (Harvey, 2008, 2011).

Since the late 2000 s the theorisation and practice of highly-skilled international migration has shifted from a discourse of migration to one of mobility, and global talent mobility. Firms now compete for talent on a global scale. Such talent has to be captured and, significantly, retained. Global talent is intrinsically, globally mobile and composed of a migratory cadre of hyper-mobile labour. Expatriation and other forms of organisational driven labour migration remains formalised into two and three or four year secondments and transfers within and between the subsidiaries of companies. However, these highly-skilled migration flows are now complemented with new forms of mobilities, like regular three to six month rotations and extended international business travel (Faulconbridge et al, 2009; Millar and Salt, 2008). In the next section of the chapter we will examine more closely the recent conceptual changes in considering highly-skilled international migration, particularly associated with economic competitiveness and the discourse of global talent.

\section{Current approaches to highly-skilled international migration}

The 'war for talent' is now a well-known phenomenon among academics and practitioners and has been discussed across a range of disciplines (Chambers et al., 1998; 
Beaverstock and Hall, 2012; Vaiman et al., 2012; Harvey, 2014). In terms of highlyskilled migrants, much of the literature has focused on the loss of talent from developing countries to developed countries under the banner of the 'brain drain' (Rapaport, 2002). However, more recently scholars have recognised that many of the highly-skilled migrants who left their developing home countries are now moving back to and/or investing in these countries (Saxenian, 2006; Tung, 2008). There is also an established literature on highly-skilled migrants who move between developed countries, particularly, but not exclusively between global cities (Beaverstock, 2005; Ewers, 2007; Harvey, 2011). Nation-states, firms and other organisations, like inter-government organisations (IGOs) and non-government organisations (NGOs), are now competing for talent from across the globe as highly-skilled labour is seen as a prized asset to create economic, social and cultural capital in an ever globalizing and expanding world economy. Global talent is now viewed as a prime ingredient for cities to aspire to 'world city status' (see, Beaverstock, 2016; Sassen, 2013) and/or a top ranking global financial centre (Z/Yen, 2014). For example, London's labour market for highly-skilled workers is now functioning at a global level and organizations seek the most skilled and qualified labour, of all nationalities, in direct competition with cities from within the European Economic Area (EEA), like Amsterdam, Berlin, Brussels, Frankfurt, Milan, Paris and Zurich, but significantly from much farther afield, like Dubai, Hong Kong, Los Angeles, New York, Shanghai, Singapore, Toronto and Tokyo (Beaverstock, 2016; Corporation of London, 2011; Jones, 2010; Kochan, 2014). The race to capture and retain highly-skilled migrants not only involve so called 'free-movers' (Favell, 2008), but also, and of strategic significance, inter- and intra-company transfers. These are people who move between and within the internal labour markets of transnational corporations, and more often than 
not these migrants reside in world cities, in close proximity to their places of work (Beaverstock, 2016; Millar and Salt, 2008; Salt, 2011).

A number of countries have recognised the value of attracting highly-skilled migrants. The Australian Government, for example, regularly updates its 'Consolidated Sponsored Occupation List', which outlines a number of priority areas such as actuaries, cardiologists, engineers, pathologists and barristers, to name only a few examples (Australian Government, 2014). New Zealand has recognised that its own talent may reside abroad, but has adopted a network approach to engage with its diaspora for business purposes through Kea New Zealand (Larner, 2007):

Kea helps the 1 million Kiwis living offshore connect with home and with one another, enabling them to share and leverage global experience, knowledge and opportunities (Kea New Zealand, 2015: np).

The Chinese Government has taken a further step to try to attract its overseas talent to return to China. In 2008, for example, it introduced its 'Thousand Talent Program', which aimed to attract 2,000 Chinese-born scholars, entrepreneurs and experts to return to China through major government funding and resources (Zhang, 2012). In short, there is a range of national government initiatives to engage with and attract talent, whether this is highly-skilled migrants or domestic talent who have left a country to study or work abroad. This has often been framed as a means of growing a country's knowledge-based economy, as has been documented in Singapore (Ho, 2011).

Singapore's Government has actively pursued a policy of attracting 'Foreign Talent' since the early 1990s. The 'Foreign Talent Programme' has been designed to entice and ease the movement of highly-skilled labour into the City-State's many highvalue knowledge intensive sectors, like academia, banking and financial services, biosciences, engineering, high technology and medicine and science (Beaverstock, 2011; Sim et al, 2003; Yeoh, 2004). Yeoh $(2004,2006)$ specifically interprets Singapore's 
overtly competitive talent seeking strategy as a key policy to build the nation's cosmopolitanism and world city credentials. At the latest count, there were over 175,000 foreign 'expatriates' in Singapore with an 'Employment Pass' (Singapore Statistics, 2015), drawn primarily from Europe, North America and the Asia-Pacific region (Australia, China, India, Japan and New Zealand) (Lewis, 2008).

However, not all countries have sent positive signals to the global labour market around attracting talent. The H-1B visa, for example, is used by US companies to attract expertise in specialist fields such as engineering, science and medicine, but it has received a lot of criticism in the country, for example, for not offering enough visas for global talent. This has led to major business leaders such as Microsoft's Chairman, Bill Gates, and News Corporation's Executive Chairman, Rupert Murdoch, warning of the major damage that a reduction in $\mathrm{H}-1 \mathrm{~B}$ visas could cause to the economic competitiveness of the US (Broache, 2008; Murdoch, 2014). The United Kingdom's (UK) Points Based System (PBS) for controlling (and tightening) highly-skilled immigration and the issuing of working visas from outside of the EEA has been interpreted by many commentators, drawn from commerce, industry and the political establishment, as being significantly detrimental to the UK's competitiveness on a global scale (The Financial Times, 2014a). The Economist (2012) boldly stated that the City of London's status as the premier financial centre was, "under threat ... [as] ... migration rules are off-putting and the political rhetoric unwelcoming". The UK Government's target to reduce the entry of Tier 2 PBS migrants (with a sponsor, including Inter-Company Transfers) across the information technology and banking, financial and professional services sectors especially, adds great weight to fear that the UK will lose out in the race for talent. This is aptly summed up by this recent headline in The Financial Times (2014b), 'Visa curbs on highly-skilled migrants hit UK talent pool”. 
Country and city survey rankings play an important role in shaping the migration decisions of highly-skilled migrants. Although this is not the only source of information that migrants are likely to use, its high circulation suggest that it is influential. HSBC's Expat Explorer Survey (2014), for example, provides information on the economy, work and social experiences as well as the environment for raising children. InterNations (2014) highlights the best and the worst places to live in terms of quality of life, ease of integrating and working, family life, personal finance and broad satisfaction. Highlyskilled migrants are not only attracted by countries, but also by particular cities where they will live and work. There are a number of notable annual rankings of cities, including The Economist's (2014) annual liveability survey, which looks at safety and environmental factors in 140 cities, and Mercer's (2015) quality of living survey which looks at a number of variables such as climate, disease, sanitation, communication, the political and social environment, and crime. The above surveys of countries and cities, which are targeted at expatriates and their employers, are important because their outcomes will likely determine migration and talent deployment decisions. Given their wide availability and circulation among global organisations and professionals, these surveys are arguably an important means for highly-skilled migrants to form impressions of destination countries and cities, which may be positive, negative or ambivalent, and will shape migration decisions.

The literature suggests that many types of skilled migrants with high levels of skills and training who are in high demand from governments and organisations (e.g. in healthcare) face labour market barriers. Some of this literature has focused on challenges based on gender (Iredale, 2001), language (Alarcón, 1999), skin colour (Mogalakwe, 2008) and class (Khadria, 2001). Williams (2007) suggests that it is less about language ability and more around assumptions of ability based on where a person received his or 
her qualification. This links to the work of van Riemsdijk (2013) who found in the context of Polish nurses in Norway that there is a particular ethnic valuation of skill. Moriarty et al. (2012) agree that stereotypes are made about particular migrant groups and their suitability for certain types of work. Zulauf (1999: 685) finds that the reputation of the secondary school and university play an important role in employment selection criteria in the City of London, and particularly in the banking sector. In the context of migrant groups, Walsh (2006) finds that British migrants in Dubai occupy a higher social status among the local Emirati population compared to other migrant groups, particularly from South Asia, as evidenced by their occupations. All of this suggests a privileged position of certain groups compared to others, which we aim to explore in greater depth below through focusing on three groups of British migrants located in different global locations to understand their experiences of network participation and employment.

There is an emerging literature on the importance of reputation and skilled migration. Harvey and Groutsis (2015), for example, argue that the reputation of home and host countries will affect whether talent stays in their current country of residence or move to another country. In particular, the reputation of countries among skilled migrants for economic opportunities, lifestyle, quality of life and other factors will influence their migration decisions. Florida (2005) makes a similar argument where talented workers in particular economic sectors such as the creative industries are attracted by lifestyle characteristics of countries and cities (e.g. aesthetics, openness to diversity and the presence of good universities). Although there are constraints such as the sector, labour market regulation and language, reputation still plays an important role in influencing migration decisions among talented workers. Other forms of reputation are also important for attracting and retaining highly-skilled migrants. The positive reputation of Samsung, for instance, has helped attract highly-skilled migrants to work in South Korea, 
including Indian software developers, who have been targeted by Samsung and the South Korean government (Kim and Lee, 2012). Similarly, Harvey (2011) found that many British scientists talked about acquiring their 'BTA' (Been To America), which referred to gaining experience of working in top universities, pharmaceutical and/or biotechnology companies in the U.S. in order to advance their careers. Here, the positive reputation of U.S. scientific institutions was an important magnet for attracting highly-skilled British migrants. In addition to reputation, various forms of social networks are important for experiences of migration and integration.

Migrant networks, clubs and associations, and the agency of place

For the highly-skilled, the production of migrant networks within their host country is an essential strategy for socialisation, both within the workplace and domestic sphere. Such migrant networks can be composed of work colleagues and their families, neighbours and friends, and acquaintances through participation in clubs, societies and/or more formal professional associations or trade bodies (e.g. Chambers of Commerce). These networks can be composed of similar nationality groups or an array of different nationalities and ethnicities, depending on an array of local factors, including occupation groups, family status, and different cultural traits of host countries. Most of the literature focused on highly-skilled international migrants or expatriates in both global South and North contexts do acknowledge that migrant networks, formal or informal, are important aspects of everyday living within the city (for example, Beaverstock, 1996; 2002; 2005; Larner, 2007; Ley, 2004; Scott, 2007; Walsh, 2006). As we have already noted, there is agreement in the literature that the workplace is a vital transnational community and place for the production of migrant networks, within and between firms, usually composed of work colleagues and wider communities (e.g. clients, members of competing firms). But, there is some disagreement in the academic literature around the degree to which skilled 
migrants participate in face-to-face social networks in host countries. Scott (2007) argues that skilled British migrants living in Paris tend to participate in such social networks, but in differentiated ways: some participate in formal immigrant associations whereas others prefer more informal gatherings in bars and cafes. These are the transnational spaces for skilled British workers in Paris. Meyer (2001) finds that many migrants from both of his Colombian and South African sample, who are working in developed countries, do not tend to participate in migrant networks. He argues that Columbian migrants are more likely to participate in migrant networks for job and professional purposes than South African migrants because Colombians experience greater differences in the education, job and cultural (including linguistic) environment in the host developed countries. In contrast, South Africans experience greater similarities when they move to countries such as the US, the UK, Canada, Australia and New Zealand, meaning they are less inclined to forge networks with other migrants compared to their Colombian counterparts (Meyer, 2001: 9). Beaverstock’s $(1996,2005)$ in-depth interview surveys of British highly-skilled migrants working in New York's financial district found that there were mixed views concerning participation in same nationality social networks for social and professional purposes. Many of these migrants were dispersed across Manhattan Island in terms of residency (i.e. there were no British enclaves identified). They socialised mainly with working colleagues, these were composed of both US and Canadian nationals and many other nationality groups, from mainland Europe, Australasia and South America. A common thread that emerged from these two surveys was that almost all the British migrants wanted to blend into the melting pot of Manhattan life and did as much as possible to distance themselves from any sort of 'expatriate' lifestyle or closely-knit sole British migration networks, whether formal or informal. Unlike in Singapore and other Asian cities like Kuala Lumpur, the 'expatriate' club scene was non-existent in New York 
(Beaverstock, 2011). For these British migrants, Manhattan Island was the manifestation of their transnational space, from the workplace and bars of Wall Street and Mid-town, to the key socialisation spaces dotted around the Up- and Mid-town areas of the borough.

Migrant networks are also vital for migrants who move from countries with different social norms to the host country because it helps with sharing common beliefs, values and interests (Hardwick, 2003). Saxenian (2006) found both a challenge for Chinese and Indian skilled migrants moving to Silicon Valley. Immigrants in her sample experienced differences in social and professional norms to the host population and often faced difficulties with finding jobs and progressing their careers. She also found that the shared experience of migration, language, education, culture and history among firstgeneration migrants forged strong ties and trusted relationships within the migrant community. These networks have meant that both groups have had great success with starting-up companies in Silicon Valley and with initiating high levels of business outsourcing to China and India.

Migrant networks are not exclusively from the same country. Beaverstock (2002: 532-533), for instance, finds that expatriates from predominantly North America, Europe, Australia and New Zealand tend to interact with each other in social clubs, and tended not to socialise with local Singaporeans unless they were clients, potential clients or potentially useful contacts. Two main reasons were cited as accounting for the lack of local Singaporeans in the British expatriates social networks. First, expatriates tended to socialise outside of work around alcohol and sporting events (e.g. rugby union and cricket) with other expatriates, frequenting social spaces which did not necessarily attract local Singaporeans who were not associated with relevant business interests. Second, many of these expatriates lived in expatriate enclaves such as Holland Village and socialised together, with their families and friends of different nationalities, i.e. those who 
lived in the same condominiums, around specific social and cultures events, or just by 'hanging out' around the pool or at BBQs. Socialising also was centred around the networks of children at international schools which invariably reproduced the interaction with other expatriates of all nationalities. What is unclear from both cases discussed above is what drives migrants to participate in migrant networks and whether they participate in such networks when they do not feel marginalised from the mainstream host society. Hagan (1998: 65) and Saxenian (2006: 63-64) argue that although migrant networks are important for helping migrants to settle, they need to expand their network beyond such networks to take advantage of weak ties from other networks.

An important form of social networks is immigrant associations, which are institutions that provide professional and social support for migrants, particularly those who have recently arrived in the host country. They can provide a range of information on: professional contacts, job information, schooling, housing and social activities. Hence, they are more than migrant networks because they do not merely provide contacts for migrants, but provide important resources which can have significant benefits for migrants (Kanas et al., 2009). Larner (2007) argues that transnational and expatriate networks, such as those associated with the New Zealand diaspora, are becoming more formalised and organised through organisations such as Kea, which is a global network that helps one million New Zealanders abroad connect with each other and with New Zealand. In other parts of the world such as the US, a number of important and powerful immigrant associations have been formed such as the Chinese Institute of Engineers (CIE) and the Indus Entrepreneurs (TiE), which have become powerful business conduits for transferring talent and resources between Silicon Valley and China and India, respectively. TiE, for example, was started by Indian entrepreneurs in Silicon Valley who wanted to help other Indian migrants to start businesses. This has helped highly-skilled Indian 
migrants to connect in the region as well as other like-minded business professionals in India. Beaverstock (2002: 533) found that skilled migrants in Singapore were encouraged and paid by their organisations (often multinational corporations) to join key business associations because of the recognition that valuable tacit knowledge can be acquired through such networks. Although in theory non-migrants are able to join the above immigrant associations, the research evidence suggests that few in practice have done so because of a lack of shared social and cultural experiences (Beaverstock, 2002; Saxenian, 2006).

Finally, we return to the agency of place, and the ideas of Smith's (1999) transnational urbanism and the functioning of migrants' social networks in producing particular spaces within the city which are confined to extremely small geographical areas like a particular bar, club or recreational park, but are constantly frequented by migrants of all nationalities. As the empirical studies above illustrate, such transnational social spaces, which could also be referred to as migrant glo-cal enclaves, are in a continuous flux, constantly being nourished by the business-social-cultural practices and performativity of highly-skilled migrants in the city. Work by Ley (2004) and Waters (2006) bring onto the agenda the role of the transnational elite, highly-skilled migrant, in making transnational social spaces within the city, augmented by similar writings of authors like Beaverstock (2002; 2005) and Conradson and Latham (2005). The remainder of this chapter explores the labour market experiences, social networks and agency of place, or spatialities, of four groups of highly-skilled British migrants in three global cities. 


\section{Methods}

The data for this paper derive from four large separate research projects on highlyskilled British migrants in Singapore (two surveys; Beaverstock 2002; 2011), Boston and Vancouver, all of which analysed their labour market experiences and social networks. These groups and settings are important because much of the literature on highly-skilled migrants has focused on groups who have faced historical barriers in host country labour markets, particularly in terms of forming networks and finding jobs (e.g. Saxenian, 2006; Hakak et al., 2010), whereas there is little recent history of highly-skilled British migrants confronting major integration difficulties in Singapore, Boston and Vancouver. Hence, we were interested to explore more deeply what experiences of labour market integration, if any, this group faced. We were also curious to explore how these different highlyskilled migrants build and reproduced social networks in particular transnational social spaces in the three cities of settlement: Singapore, Boston and Vancouver.

Interviewees were selected and conducted with British-born migrants with high levels of education and training (typically a minimum of a university degree or equivalent and at least three years of paid or unpaid employment). Interviewees varied in age from early 20 s to 70 s, but typically they were in their 40 s and in the middle of their careers. Interviewees worked in a range of sectors, but most were working in finance and professional services, including but not limited to investment banking, hedge funds, law, management consulting, accounting, engineering, health science and architecture. Interviews lasted for 45 minutes to one hour and were conducted by at least one of the authors with 48 interviewees in Singapore (1999 and 2004), 101 interviewees in Boston (2006) and 64 interviewees in Vancouver (2009). Interviewees across the three locations were a broad mixture of inter-company transfers (sometimes referred to as 'assigned expatriates') and self-initiated skilled migrants (sometimes referred to as 'self initiated 
expatriates'). There was a stronger emphasis on inter-company transfers in Singapore compared to in Boston and Vancouver, but this was not stark enough to infer any relationship between the type of migrant and his or her networking behaviour. A number of avenues were pursued for gaining access, including employers, personal contacts, expatriate websites, government sources and local sports and social clubs. These broad range of avenues ensured that a cross-section of highly-skilled migrants were interviewed rather than a particular subset group. The majority of interviews were conducted in person in the cities, but a small number of interviews were conducted over the telephone when interviewees were unable to attend face-to-face interviews. We use pseudonyms below to protect the identities of participants and their employers.

A number of open-ended questions were asked around individual experiences as inter-company transferees, finding work, social networking and conducting business in the host country, and the importance of particular places for migrant socialisation. Certain a priori themes such as work opportunities, challenging work, social networks, immigrant associations and social clubs, and place were explored before analysing the data, although these were limited to avoid issues of biasing the analysis of the interviews (Brooks and King, 2014). We analysed and categorised our data manually following the above themes. Our themes were formulated through identifying recurring features during interview accounts of their work and networking experiences.

\section{Findings}

This section focuses on the integration experiences of highly skilled British migrants working in three different global cities: Singapore, Vancouver and Boston. 


\section{Work and socialisation in Singapore}

As discussed above, Singapore's political establishment is pro-talent and actively seeks foreign workers within its 'Foreign Talent Programme' to fill vacancies across a range of commerce, industry and public services. All of the migrant interviewees were referred to as 'expatriates' by themselves and the State, and they were issued with Employment Pass visa entry. Interviewees entered Singapore as either intra-company transfers (i.e. moving with the firm on defined expatriate programmes and resettlement packages) or inter-company transfers (i.e. moving between firms, but mostly receiving expatriate programmes and resettlement packages). The dependents interviewed, the socalled, 'trailing spouses' (Yeoh and Khoo, 1998), were more often than not, female. Ten 'trailing spouses' were interviewed from the total of 48 (all in 2004), of which eight were female. A common denominator for all of these migrant workers was that they lived privileged lifestyles in Singapore. They received relatively high incomes in a very low personal taxation regime. They lived in exclusive condominium developments or for the more affluent, large detached houses, all with facilities like swimming pools and gyms. Their children were enrolled in the best international schools in Singapore, and they maintained very strong social networks with their peer groups, most often other British or Australian/New Zealand or other European nationalities. In almost all cases, these highly-skilled British migrants were associated with clubs and other formal entities linked to both social and working environments. All of these expatriate territories, the home, workplace and recreational space, were classic forms of transnational social spaces, where migrant networks were produced, replenished and articulated in tightly bounded geographical localities within the city.

Thirty-seven of the 48 interviewees were employed in both domestic and foreign firms in Singapore, and predominantly in the banking, and financial and professional 
services sectors (the remainder were dependents and interviewed as participants in The British Club). Thirty-four of these 37 (92\%) were men, further reinforcing the gender bias in highly-skilled migration, and global financial centres where business networks have been significantly gendered (Kofman and Raghuram, 2006; McDowell, 1977). Upward of three-quarters of these migrants were married and had their families in Singapore, which is important because a lot of socialisation in this group were in expatriate clubs, which were important conduits for both social and professional networking. From an organisational perspective, these migrants had so called transnational career paths. They had often experienced working and living in other world cities outside of the UK, most notably in Europe and elsewhere in Asia. For these migrants, a key motivation to be an expatriate and working in Singapore was the ability to accumulate new knowledge, both codified and tacit, transfer existing knowledge to the Singaporean workplace, and use their 'softer' socialisation skills to build both social and cultural capital, within and outside of the workplace in particular transnational spaces within the city (Beaverstock, 2002). All of these migrants had very few problems with respect to entry into Singapore, dealing with the Government, and organising day to day activity like living and schooling, and working in the downtown business district.

A significant aspect of migrant socialisation and network building in Singapore was participation in both informal and formal activities, which also became very important transnational social spaces for knowledge accumulation. At one level, the bars and restaurants in proximity to the downtown financial centre and business district were vital transnational spaces for social interaction, particularly with work and non-work colleagues, mainly those who had been 'western educated'. Specific events, like the Singapore Rugby Sevens, Formula 1 Grand Prix, were vital moments in time and sites for networking and building social contacts and future knowledge streams, when mixing with 
other nationalities, often corporate clients and competitors. Membership of prestigious clubs and societies, also frequented by the Singaporean local elites, like the Singapore Cricket Club, The Tanglin Club and The British Club became, and still are, key transnational social spaces for migrant network building, for business and social purposes. As Beaverstock (2011) found, membership of a club was a vital asset for migrants to socialise with other transnational elites, of all nationalities, but mainly 'western'. Such clubs had strong membership numbers among western expatriates and represented an important space where interviewees built trusted relationships with other expatriates through shared experiences, including with family members and friends. In many ways, all of the British expatriates interviewed in Singapore had highly successful working, household and social lives because of their propensity to get embedded in Singapore's transnational spaces, both the workplace and those expatriate bars and restaurants down on the Waterfront. To forge a successful transnational career in Singapore, therefore, was not only linked to a fruitful and positive working experience in the firm, but also the ability to develop and sustain strong social networks in particular transnational spaces of the city.

Moving onto the club scene in Singapore, a vitally important place for the articulation of migrant social networks, the establishment of social and recreational clubs in Singapore can be traced back to the 1850 s onwards, linked most closely to the city's colonial infrastructure and position as a vital merchant port for the British Empire (Sharp, 1993; Walsh, 1991). Post-independence in the 1970s, the established clubs like the Cricket Club (1852), Tanglin Club (1865), Hollandse Club (1908), were joined by new entrants like the American Club, British Club and specialist business clubs, like the Tower Club. By the late 2000s there were over 100 clubs in Singapore (www.cmas..org.sg). Many of these clubs became highly popular with both Singaporean 
local elites, from a range of sectors of the economy, and Singapore's expatriate workers. These clubs performed two main functions for the British migrants: first, they provided recreational facilities and served as transnational 'meeting places' for families and thus assisted with social acclimatisation in Singapore; second, they acted as places for business-related networking, alongside the formal workplace. By the turn of the TwentyFirst century, these clubs and recreational spaces were very much transnational in scope and no longer 'badge' or labelled as solely places for 'expatriates' to socialise and network (Beaverstock, 2011).

Following the global financial crisis, Singapore has gained significant economic status in the Asia-Pacific, and it remains a highly prized world city location for British highly-skilled workers, and other nationalities. It is considered an important place to advance careers particularly in leading global transnational corporations across a range of industrial sectors, particularly given its proximity to China. Data from Singapore's Ministry of Manpower (2015) shows that the number of Employment Passes issued to 'expatriate' workers has increased by $+55 \%(+62,300)$ from 114,300 to 176,600 between December 2009 and June 2014.

\section{Challenging work and professional practice in Vancouver}

The experiences of highly-skilled migrants in Vancouver was much more integrated into mainstream Canadian social and business life compared to the experiences of highlyskilled British migrants in Singapore. Nonetheless, British migrants in Vancouver said that their experiences of working in Vancouver was often different than the experiences of the local population (see Harvey, 2012). Some interviewees, for example, argued that they received greater opportunities in the workplace. For instance, over $40 \%$ of interviewees were provided with greater levels of responsibility and expectation compared to their previous job roles in the UK. In particular, because British workers had 
prior experience of working in the UK and in Canada, they were often asked to work with clients and customers in both locations because of their business and cultural knowledge of both countries. In some instances, the reputation of British business played an important role in providing highly-skilled migrants with additional opportunities. Briony Barker, for example, worked for one of the major UK publishers before moving to Canada and she found that she received a much higher level of responsibility because the reputation of her previous employer was a proxy for her own capabilities. In short, many Canadian employers valued British qualifications and experience, which provided highlyskilled migrants with greater labour market opportunities than their Canadian counterparts. In the words of David Nelson, Partner of an architecture firm, "Years ago I think British architects were held in pretty high esteem [...] that's still the case but not as much as in the eighties. British-educated people have a good experience, with parliamentary effect". This has parallels with the work of Walsh (2006) who found that British expatriates in Dubai often received greater professional opportunities than other migrant groups.

The literature on the labour market experiences of highly-skilled migrants has tended to emphasise the challenges that many migrant groups have faced (Saxenian, 2006; Liversage, 2009; Hakak et al., 2010). In general, British migrants in Vancouver were satisfied with their Canadian employers, with the mean British migrant stating that they felt highly valued by their employer ( 8.3 out of 10$)$. British migrants were also satisfied with their salaries, scoring this as 7.3 out of 10 .

Despite the generally positive picture of working in Vancouver, $29 \%$ of interviewees said that they had faced problems obtaining work in Vancouver, which included having their skills recognised. One problem that was faced in certain sectors was professional body protectionism with a lack of transferability of qualifications required to practice. As Ian Piper stated: "The issue is there is a certain amount of 
protectionism of professions. They don't want foreigners; it's never far under the surface." The implication here was that in certain professions such as law and engineering, it was irrelevant what prior experience highly-skilled migrants had because they needed to gain the requisite qualifications in Canada. This links closely to the argument of Zulauf (1999: 683) who argues that employers and professional bodies have a high degree of discretion when it comes to recognising different credentials to enable individuals to practice in their profession.

There was sometimes a lack of alignment between the rhetoric of the Canadian Government, which sought to attract highly-skilled migrants through open-door immigration policies, and labour market policies, which restricted many of these migrants from working in Canada in their field. This has short-term implications for the retention of highly-skilled migrants and long-term implications for the attraction of highly skilled migrants as potential workers will be put off from moving if they face problems with not working in an area commensurate with their training and skills. Salaff et al. (2002) also refer to this tension between immigration policy and institutional conditions and the importance of both aligning.

Some British migrants (22\%) said that they were expected to prove themselves before they were treated equally. In the words of Lionel Myler, a design engineer, "Basically I think for the first eighteen months I had to prove myself, and not just professionally but in my long term intentions." He went on to say how he was expected to gain permanent residency and become an accredited professional engineer locally. This experience, which was similar to a number of highly-skilled British migrants, serves to show some of the major labour market challenges that migrant workers faced. Simon Beech, a lawyer, went further describing the "insular environment" which did not 
recognise "international experience", which he found highly frustrating given his extensive international experience of practicing law abroad.

In summary, the experiences of British migrants in the workplace across a wide range of age generations and economic sectors in Vancouver was far from homogeneous. This suggests that there was not one common narrative (i.e. positive, negative or ambivalent) which encapsulated this group's experience. Nor was there a particular place or space that this group occupied professionally or socially in the city, which was evident among British migrants in Singapore, with perhaps the exception of the formal workplace, and surrounding bars and restaurants. In short, British migrants in Vancouver tended to be comfortable occupying business and social spaces with the local population rather than spaces which were predominantly or exclusively occupied by migrant groups.

\section{Lack of migrant networks in Boston}

Highly-skilled British scientists in Boston, like highly-skilled British migrants in Vancouver, showed a general lack of participation in social networks (see Harvey, 2008). Despite the fact that there are a large number of British scientists in Boston, there was a general lack of participation in migrant networks, either British or other nationalities for professional or social purposes. The median British interviewee, for instance, attended only one British-related networking event a year and $44 \%$ of British interviewees said that they did not attend any business-related events with people from the UK. Some scientists actively recoiled from networking with other British migrants as Rory Greig, CEO of a small biotechnology company, argued: "I actively avoid networking with the Marmite brigade. I believe when in Rome do as the Romans do." The implication here was that British migrants did not wish to network with other British migrants when living abroad because they wanted to interact with other groups. Other British migrants did not see what they would benefit from interacting with other British migrants per se. These 
findings are in contrast to British expatriates in Singapore's financial district where interviewees considered their participation in such networks in particular transnational spaces with the city as integral to their 'survival' in Singapore (Beaverstock, 2002: 535). One explanation for this might be cultural and environmental differences between Singapore and the UK where British migrants found certain social spaces like expatriate clubs, bars and residential areas a safe haven compared to other spaces of the city where cultural challenges and tensions were more pronounced. Saxenian (2006) argues that Chinese and Indian engineers in Silicon Valley formed immigrant associations as a strategy to overcome biases in the labour market, which through organisations such as the Chinese Institute of Engineers and the Indus Entrepreneurs, have subsequently become sources of competitive advantage for skilled migrants.

Outside of socialisation in the formal workplace, professional events were organised in Boston for highly-skilled British migrants. The Science and Technology Department of the British Consulate held a range of events around Boston. These typically targeted migrants who held highly senior positions. Murray Lake, VicePresident of a global strategy and consulting firm, said that although these events were important for networking, he would like to have seen more of these events when he first moved to the US: "There was no social club, no outreach with the British Government [...] I would like to have seen more of that when I was a grad student". Indeed, it was telling that junior scientists cited a lack of such networking events in the region. Niall George, CEO of a small biotechnology company, was highly disappointed with the lack of engagement and commitment from the UK Government stating: "I have had some of my passions whittled away from me in terms of my government treatment”. Although there were British associations that were organised independently of the UK government, they had varying success in terms of participation. 
There was generally little demand for British immigrant associations among highly-skilled migrants, but it was not clear whether this was because existing opportunities were absent or ineffective, or whether there was simply little demand from British migrants for such associations. A number of British interviewees, for example, said that they would like to have more participation from the British Consulate in terms of communicating to them relevant opportunities in the US and the UK, particularly when they first arrived in the US and had had limited social networks around Boston. British Expats in Life Sciences (BELS), which had some informal but no official links with the UK government, was the only British association in the life sciences sector in Boston. There were a small number of British scientists who attended BELS events regularly ( $10 \%$ of British interviewees in Boston). Even those people that did attend BELS events said that they were more useful for consolidating social contacts than for forging new contacts. There was also a recognition that the British tended to network with other British migrants in a more limited capacity than other migrant groups. Cameron Timpson, scientist at a large biotechnology company, found the BELS events tended to have fewer attendees compared to other migrant associations, which was indicative of nationalspecific networking within his company: "There is quite a large Chinese group, quite a large Russian group and Indians in the company. They tend to bunch together more than the British [...] Maybe it's the national language thing." In the words of Charles Watkins, Chief Scientific Office of a medium biotechnology company, “As a general rule, I don't think the British group are particularly nationalistic." However, this does not explain the varying networking patterns between British migrants in different global locations. The above findings are in contrast to other migrant groups such as the British in Singapore (Beaverstock, 2002), Paris (Scott, 2007) and Dubai (Walsh, 2006) where there is extensive networks and use of transnational social spaces among the British. This 
arguably may be explained by more marked differences in language and/or culture between Britain and the host country compared to the context of British migrants in Boston. In other words, British migrants in Vancouver and Boston felt closer linguistically and culturally to the host population than British migrants in Singapore, Paris and Dubai where there were stronger linguistic and cultural divides, which led to migrants forging closer connections with other British or expatriate groups. In short, place is important in determining participation in social networks. However, it not so much geographical distance that seems to determine participation in migrant-specific networks, but more linguistic, cultural or social distance (Neeley, 2015).

A sizeable proportion of British interviewees in Boston (43\%), all of whom worked in the life sciences sector, had heard of British associations such as BELS. However, only $16 \%$ of interviewees said that they were important to them for professional networking such as hearing about new trends in the field or new job or professional development opportunities. The data suggest that there were both British migrants who were not aware of immigrant associations and those who were aware but chose not to participate in such organisations. Paul Lyons, Director of a small biotechnology company, recognised that there were a lot of people in Boston from the UK, but questions the business value of BELS: "BELS, it's great for a social get together, but I'm not sure it helps necessarily with your networking because you don't necessarily need people from the UK in the same room.” James Churt, Vice-President of a large pharmaceutical company, made a similar observation of his own experience: “I guess I wasn’t just interested in getting together with expats per se". Participation in such associations were entirely at the discretion of migrants, whereas clubs in Singapore were discretionary for migrants, but often encouraged and paid for by their employers because of the recognition 
of their business value for sourcing talent, clients and investment (Beaverstock, 2002: $535)$.

In summary, despite the fact that British migrants in Singapore, Vancouver and Boston were similar in terms of their social and professional characteristics, there were marked differences in their networking experiences with other British migrants. British migrants in Singapore actively engaged in migrant networks which were practiced and performed in particular transnational social spaces, where an agency of place was reproduced both through expatriate clubs and directly with other 'western' migrants. This was driven by both personal desire to forge social networks and by the expectations of multinational employers for expatriates to professionally network with other expatriates for establishing and maintaining business relationships, which were often spatialised outside of the work place in the wider financial district and downtown area (in for example, bars, restaurants and clubs). In contrast, British migrants in Boston and Vancouver tended to engage significantly less in both formal migrant associations as well as in forging networks with other British migrants, whether these were for professional or social purposes. There was not only less appetite on an individual basis, but employers of British migrants in Boston and Vancouver did not encourage or provide any incentives for participation in formal migrant associations. For many of the highly-skilled British migrants in Boston and Vancouver they had no concrete affinity to particular transnational social spaces with the city like the British in Singapore, except the formal workplace and selected bars and restaurants. Moreover, salient findings from the Boston and Vancouver studies actually suggest that these migrants did everything in their decision-making to avoid what many of them saw as the 'cringing' experiences of socialising with other expatriate communities in designated spaces, whether that be bars or social and recreational clubs. 


\section{Conclusions}

This chapter has provided an overview of the main theoretical literature and practices of highly-skilled migration. We began by showing that countries, regions and organisations are increasingly seeking to attract highly-skilled migrants from a range of different countries. Importantly, it is not only countries and cities which have historically sourced highly-skilled migrants, but emerging economies as well, which is increasing competition between countries for this finite resource. At the same time, we are seeing a greater trend towards mobility than migration meaning that highly-skilled migrants are moving across the globe more frequently, requiring governments and organisations to be more active in both attracting and retaining talent. Surprisingly, we observe some national governments such as the US and the UK adopting lukewarm approaches to attracting highly-skilled migrants as a response to concerns in both countries around high volumes of immigration, despite strong business pressure to attract greater numbers of highly-skilled migrants. This is occurring at a time when countries such as China and Singapore are actively seeking out highly-skilled talent, including engaging with their own talent who are working abroad. All of this is important because these different government approaches send very strong reputation signals to potential talent looking to work in different countries. We also highlight the importance of country and city surveys, which rate and rank different destinations based on a range of criteria, again signalling the importance of reputation for influencing migration decisions. This is significant because such reputational indicators are important for a sizeable number of potential migrants who are seeking to live and work abroad, but have yet to apply for specific job opportunities.

An important conclusion to note is that our comparative study of British highlyskilled migrants in Boston, Singapore and Vancouver offers mixed perspectives in conceptualising the agency of place, transnational social spaces, in the wider theories 
regarding highly-skilled labour migration. At the macro-scale, the city and prefix of the global/world city are well known as the key sites where highly-skilled migrants want to work and live, to enhance career paths and personal income, and enjoy unparalleled opportunities for social and culture living, and consumption. In our studies, all three cities are highly attractive locations for highly-skilled migrants, lured by the prospects of their corporate and high-value economies and opportunities for developing both social and cultural capital. But, we begin to discover divergence in the (re)production of social networks and use of distinctive transnational social space by our highly-skilled migrants at the micro-level. On the one hand, the migrants in the North American cities do their utmost to 'go it alone' and shy away from participation in same or other nationality social networks and socialise in well-known transnational social spaces because they want to, as one participant noted, “...when in Rome do as the Romans do.” On the other hand, all the British expatriates working in Singapore relied on participation in social networks, both formal and informal, made up of same and like-minded nationalities (Australians, New Zealanders, South Africans) which were practiced and performed in distinctive transnational social spaces like the bars and restaurants on Clarke and Boat Quays, at expatriate clubs and various sporting events. This is not out of place with other studies of British people in non-Western contexts, like the British in Dubai (Walsh, 2006). From our studies we would conclude that the agency of place for these British highly-skilled workers is much stronger in a non-Western context, where households tend to live in same nationality enclaves, and workers tend to socialise with similar ethnic groups in distinctive 'Western' spaces like bars, clubs and sporting clubs, than in a Western context like North America where residential preferences are one of dispersion in the city and membership of same or similar nationality social networks are very weak. Both Boston and Vancouver do not have the equivalent of expatriate enclaves like Holland Village in 
Singapore. In an Asian and other non-'Western' contexts, the practice and performance of migrant social networks in exclusive transnational social spaces remain significant relational territories for both business, and social and cultural activities within the city. Some 'Western' examples exist such as the British networking with other migrant groups in Paris (Scott, 2007), but again these may be explained by linguistic and cultural differences between the migrant group and the local population, as is typically found with 'Western' migrants living in non-'Western' countries (and vice-versa).

The literature on highly-skilled migration highlights the importance of social networks for both migration and integration into the host country. We show across four studies in three different global cities that the experiences of working and socialisation can vary significantly geographically even among migrants who share similar social and professional characteristics. Highly-skilled British migrants in Singapore, for example, painted quite a positive picture of working in Singapore where the government and organisations were keen to attract and retain these types of workers. British migrants in Vancouver, however, found that although the government was keen to attract them to work in Canada, the experience of work was quite divided, with some workers clearly receiving greater opportunities and responsibility, whereas others found themselves having to prove themselves or in some sectors re-accredit with little recognition of their prior education, training and international experience. British migrants in Boston generally experienced positive signals and opportunities from their employer, but more recent migrants faced difficult immigration policies, which included the time lag from converting from immigrant status to permanent resident to citizen.

We also found variation in the use of social networks and frequenting of particular transnational social spaces within the city among different highly-skilled migrant groups. British migrants in Singapore, for example, tended to strongly socialise with other 
expatriates from the UK and other countries, with limited socialisation with Singaporeans. This was because of socio-cultural differences in work-related leisure activities focused around downtown bars and specific sporting and other social events. In addition, these expatriates tended to live in 'expatriate enclaves', with families, which tended to reproduce expatriate socialisation, as discussed above. This is similar to the experiences of British migrants in Paris and Dubai, where there is a production and reproduction of expatriate social networks in distinctive transnational social spaces like bars, restaurants, sporting and recreational sites, as well as 'expatriate' clubs. However, this is in contrast to highly-skilled British migrants in Vancouver, Boston and New York where people were dispersed across the cities, with very little affinity to migrant transnational social spaces like the British in Singapore. In addition, in our studies in these cities, there was some social and professional interaction with other British expatriates, but it was much less common because interviewees found it limiting to their social and professional lives. This is an important finding because highly-skilled British migrants, although fairly homogenous in their education, skills and background, varied markedly in their engagement in expatriate social networks and transnational social spaces. Some groups such as the British in Singapore rely on both social networks and participation in transnational social spaces to 'survive' in the host country, while other groups such as the British in Boston strongly 'recoiled' and looked down on such social behaviour and sites for the articulation of transnationalism in the city.

Theoretically, this chapter raises important questions around why some highlyskilled migrant groups engage and others disengage with such networks and transnational social spaces. In particular, we suggest that wider differences in cultural norms between the host country compared to the home country will increase the propensity of migrants to participate in migrant associations, networks and transnational social spaces and for their 
multinational employers to support such participation. Practically, we suggest that there are potentially important strategic opportunities for the UK Government and organisations to foster and engage with highly-skilled migrant business networks in host countries, which are largely privately organised, to help forge business ties, foreign direct investment and talent flow opportunities. These have hitherto been under-utilised in the context of British migrants in Singapore, Boston and Vancouver and yet have proved highly fruitful for other skilled migrant groups in other places such as New Zealand, China, Taiwan, Israel and India (Saxenian, 2006, Larner, 2007). Having said this, we would suggest that in a similar function to effective alumni networks, such ties need to be proactively formed at the early stages of a highly-skilled migrant's mobility, rather than reactively waiting until that migrant has become successful in his or her career. Finally, we have found that sometimes there was a disconnect between immigration policy (i.e. national approaches to attracting skilled migrants) and labour market policy (i.e. the ability of skilled migrants to work in the host country, particularly in certain professions where there were high levels of labour market protectionism imposed by professional bodies). We would argue that greater alignment would help to ensure that the expectations of highly-skilled migrants are met, which will have important long-term future implications for both the attraction and retention of global talent.

\section{References}

Alarcón, R. 1999. Recruitment processes among foreign-born engineers and scientists in Silicon Valley. American Behavioural Scientist 42 (9): 1381-1397.

Appleyard, R. 1991. International Migration. Challenge for the Nineties. Geneva: IOM. 
Australian Government. 2014. Consolidated sponsored occupations list. https://www.immi.gov.au/Work/Pages/skilled-occupations-lists/csol.aspx Last accessed $05 / 08 / 2014$

Bach, S. 2011. Migration and International HRM. In International human resource management: Globalization, national systems and multinational companies, eds. T. R. Edwards and C. Rees, 272-293. Harlow: FT Prentice Hall.

Beaverstock, J.V. 1996. Re-visiting high-waged labour market demand in the global cities: British professional and managerial workers in New York City. International Journal of Urban and Regional Research 20 (4): 422-445.

Beaverstock J.V. 2002. Transnational elites in global cities: British expatriates in Singapore's financial district. Geoforum 33 (4): 525-538.

Beaverstock, J.V. 2004. Managing across borders: Transnational knowledge management and expatriation in legal firms. Journal of Economic Geography 4 (2): 157179.

Beaverstock, J.V. 2005. Transnational elites in the city: British highly-skilled inter-company transferees in New York City's financial district. Journal of Ethnic and Migration Studies 31 (2): 245-268.

Beaverstock, J. V. 2007. World city networks from below: International mobility and inter-city relations in the global investment banking industry. In Cities in globalization: Practices, policies, theories, eds. P. J. Taylor, B. Derudder, P. Saey, and F. Witlox, 52-71. London, Routledge.

Beaverstock, J.V. 2016. Global mobility and knowledge management in professional service firms. In Spatial Mobility of Knowledge, eds. P. Meusburger, H. Jöns, and M. Heffernan. Springer: Berlin (in press). 
Beaverstock, J.V. and S. Hall. 2012. Competing for talent: global mobility, immigration and the City of London's labour market. Cambridge Journal of Regions, Economy and Society 5 (2): 271-287.

Broache, A. 2008. Bill Gates to congress: Let us hire more foreigners. CNET http://www.cnet.com/news/bill-gates-to-congress-let-us-hire-more-foreigners/ Last accessed 05/08/2014.

Brooks J. and N. King. 2014. Doing template analysis evaluating an end of life care service. Sage Research Methods Case.

Castells, M. 2000. The Rise of the Network Society. Oxford: Blackwell.

Castells, M. 1989. The Informational City. Oxford: Blackwell.

Chambers, E.G., M. Foulon, H. Handfield-Jones, S. M. Hankin, and E. G. Michaels. 1998. The war for talent. McKinsey Quarterly 1 (3): 44-57.

Conradson, D. and A. Latham. 2005. Transnational urbanism: Attending to everyday practices and mobilities. Journal of Ethnic and Migration Studies 31 (2): 227233.

Cormode, L. 1994. Japanese Foreign Direct Investment and the circulation of personnel from Japan to Canada. In Population migration and the changing world order, eds. A. Findlay and W. T. S. Gould, 67-89. Chichester: Wiley.

The Corporation of London. 2011. Access to global talent. The impact of migration limits on UK financial and professional business services. London: The Corporation of London.

Ewers, M. C. 2007. Migrants, markets and multinationals: competition among world cities for the highly skilled. GeoJournal 68 (1): 119-130. 
The Economist. 2012. Immigration and business - A harder road. October 20th' http://www.economist.com/news/britain/21564895-government $\%$ E2\%80\%99s-policystudents-and-skilled-migrants-threatens-do-long-term-damage Last accessed 05/08/2014.

The Economist. 2014. The best places to live. http://www.economist.com/blogs/graphicdetail/2014/08/daily-chart-13 Last accessed $18 / 02 / 2016$

Edstrom, A. and J. Galbraith. 1977. Transfer of managers as a coordination and control strategy in multinational corporations. Administrative Science Quarterly 22 (June): 248-263.

Faulconbridge, J., J. V. Beaverstock, B. Derudder, and F. Witlox. 2009. Corporate ecologies of business travel: Working towards a research agenda. European Urban and Regional Studies 16 (3): 295-308.

Favell, A. 2008. Eurostars and Eurocities: Free movement and mobility in an integrating Europe. Oxford: Oxford University Press.

Findlay, A. 1990. A migration channels approach to the study of high level manpower movements: a theoretical perspective. International Migration 28 (1): 15-23.

The Financial Times. 2014a. Visa curbs on highly-skilled migrants hit UK talent pool. http://www.ft.com/cms/s/0/1019b05a-0202-11e4-9af7-00144feab7de.html\#slide0 Last accessed 30/07/2014.

The Financial Times. 2014b. New York ousts London as top financial centre. http://www.ft.com/cms/s/0/9a8fbf6a-ab89-11e3-aad900144feab7de.html\#axzz39Wp11Cgw Last accessed 30/07/2014.

Hagan, J.M. 1998. Social networks, gender, and immigrant incorporation: Resources and constraints. American Sociological Review 63 (1): 55-67. 
Hakak L.T., I. Holzinger, and J. Zikic. 2010. Barriers and paths to success: Latin American MBAs' views of employment in Canada. Journal of Managerial Psychology 25 (2): 159-176.

Hardwick, S.W. 2003. Migration, embedded networks and social capital: Towards theorising North American ethnic geography. International Journal of Population Geography 9 (2): 163-179.

Harvey, W.S. 2008. The social networks of British and Indian expatriate scientists in Boston. Geoforum 39 (5): 1756-1765.

Harvey, W.S. 2011. British and Indian scientists moving to the United States. Work and Occupations 38 (1): 68-100.

Harvey, W.S. 2012. Labour market experiences of skilled British migrants in Vancouver. Employee Relations 34 (6): 658-669.

Harvey, W.S. 2014. Winning the global talent war: A policy perspective. Journal of Chinese Human Resource Management 5 (1): 62-74.

Harvey, W.S. and D. Groutsis. 2015. Reputation and talent mobility in the Asia Pacific. Asia Pacific Journal of Human Resource Management 53 (1): 22-40.

Ho, E. L. E. 2011. 'Claiming' the diaspora: elite mobility, sending state strategies and the spatialities of citizenship. Progress in Human Geography 35(6): 757-772.

HSBC 2014. Expat Explorer Survey. https://expatexplorer.hsbc.com/survey/?HBIB_dyn_lnk=hme_nav t4 col1_lnk_1 Last accessed 30/07/2014. 
InterNations 2014. The Best \& Worst Places for Expats.

http://www.internations.org/expat-insider/2014/the-best-and-worst-places-for-expats Last accessed 30/07/2014.

Jones, A. 2010. Immigration and the UK labour market in financial services: A case of conflicting policy challenges? In A Need for Migrant Labour? Labour Shortages, Immigration and Public Policy, eds. M. Ruhs and B. Anderson, 259 - 289. Oxford: Oxford University Press.

Kochan, B., ed. Migration and London's growth. London: London School of Economics Books.

Iredale, R. 2001. The migration of professionals: Theories and typologies. International Migration 39 (5): 7-26.

Kanas, A., F. van Tubergen, and T. van der Lippe. 2009. Immigrant self-employment: testing hypotheses about the role of origin- and host-country human capital and bonding and bridging social capital. Work and Occupations 36 (3): 181-208.

Kea New Zealand. 2015. Kea. New Zealand's global network. http://www.keanewzealand.com/what-is-kea/ Last accessed 18/02/2016.

Khadria, B. 2001. Shifting paradigms of globalisation: The twenty-first century transition towards generics in skilled migration from India. International Migration 39 (5): $45-71$

Kim Y-H. and Lee J.A. 2012. To outdo rivals in mobile software, Samsung turns to outside talent. Wall Street Journal. http://online.wsj.com/article/SB1000142405270230387760457738160175 8850814.html Last accessed 30/07/2014.

King, A. 1976. Colonial urban development. London: Routledge. 
Kofman, E. and Raghuram, P. 2006. Women and global labour migrations: incorporating skilled workers. Antipode 38 (2): 282-303.

Larner, W. 2007. Expatriate experts and globalising governmentalities: the New Zealand diaspora strategy. Transactions of the Institute of British Geographers 32 (3): $331-345$.

Lewis, L. 2008. The 'little red dot' intent on becoming the hub that Asia cannot live without. The Times, Saturday October 11th, 64-65.

Ley, D. 2004. Transnational spaces and everyday life. Transactions of the Institute of British Geographers 29 (2): 151-64.

Liversage A, 2009. Vital conjunctures, shifting horizons: High-skilled female immigrants looking for work. Work, Employment and Society 23 (1): 120-141.

McDowell, L. 1997. Capital culture: Gender at work in the city of London. Oxford, Blackwell.

Mercer. 2015. Newsroom. Vienna tops latest Quality of Living rankings. http://www.uk.mercer.com/content/mercer/europe/uk/en/newsroom/2015-quality-ofliving-survey.html Last accessed 18/02/2016.

Meyer, J.B. 2001. Network approach versus brain drain: Lessons from the diaspora. International Migration 39 (5): 91-110.

Millar, D. and J. Salt. 2008. Portfolios of mobility: The movement of expertise in transnational corporations in two sectors - aerospace and extractive industries. Global Networks 8 (1): 25-50.

Mogalakwe, M. 2008. The making of a foreign 'labour aristocracy' in Botswana. Employee Relations 30 (4): 422-435. 
Morgan, G. 2001. Transnational communities and business systems. Global Networks 1 (1): 113-130.

Moriarty, E., J. Wickham, T. Krings, J. Salamonska, and A. Bobek 2012. 'Taking on almost everyone?' Migrant and employer recruitment strategies in a booming labour market. The International Journal of Human Resource Management 23 (9): 1871-1887.

Murdoch, R. 2014. Immigration reform can't wait, Wall Street Journal. http://online.wsj.com/articles/rupert-murdoch-immigration-reform-cant-wait-1403134311 Last accessed 18/02/2016.

Neeley, T. 2015. Global teams that work. A framework for bridging social distance. Harvard Business Review 93 (10): 75-81.

Rapaport, J. 2002. Who is afraid of the brain drain? Human capital flight and growth in developing countries. Stanford Institute for Economic Policy Research, Policy Brief. Palo Alto, California.

Salaff, J., A. Greve, and X. L. Ping. 2002. Paths into the economy: Structural barriers and the job hunt for skilled PRC migrants in Canada. International Journal of Human Resource Management 13 (3): 450-464.

Salt, J. 1988. Highly-skilled international migrants, careers and internal labour markets. Geoforum 19 (4): 387-399.

Salt, J. 2011. Migration to and from the UK. In Global Migration, Ethnicity and Britishness, eds. T. Modood and J. Salt, 14-39. Basingstoke: Palgrave Macmillian, Salt, J. and A. Findlay. 1989. International migration of highly-skilled manpower: Theoretical and developmental issues. In The Impact of International Migration on Developing Countries, ed. R. Appleyard. Paris: OECD Publications. 
Sassen, S. 1991. The global city: New York, London, Tokyo. Princeton: Princeton University Press.

Sassen, S. 2013. Cities in a world economy. London: Sage (4th Edition).

Saxenian, A. 2006. The new argonauts. Regional advantage in a global economy. Cambridge, MA: Harvard University Press.

Scott S., 2007. The Community morphology of skilled migration: The changing role of voluntary and community organisations (VCOs) in the grounding of British identities in Paris (France). Geoforum 38 (4): 655-676.

Sharpe, I. 1993. Singapore Cricket Club 150th Anniversary (1852-2002). Singapore: The Singapore Cricket Club.

Sim, L.L., S. E. Ong, A. Agarwal, A. Parsa, and R. Keivani. 2003. Singapore's competitiveness as a global city: Developing strategy, institutions and business environment. Cities 20 (2): 115-127.

Singapore Ministry of Manpower. 2015. Foreign workforce numbers www.mom.gov.sg Last accessed 18/02/2016.

Smith, M.P. 2001. Transnational urbanism: Locating globalization. Oxford: Blackwell.

Smith, M.P. 1999. Transnationalism and the city. In The urban movement, eds. R. Beauregard and S. Body-Gendrot, 119-139. London: Sage.

Sparrow, P., C. Brewster, and H. Harris. 2004. Globalizing human resource management. London: Routledge.

Tung R.L. 2008. Brain circulation, diaspora, and international competitiveness. European Management Journal 26 (5): 298-304. 
Tung, R.L. 1988. The new expatriates: Managing human resources abroad. Cambridge MA: Ballinger.

Vaiman, V., H. Scullion, and D. Collings. 2012. Talent management decision making. Management Decision 50 (5): 925-941.

van Riemsdijk, M. 2013. Everyday geopolitics and the valuation of labor: International migration and socio-political hierarchies of skill. Journal of Ethnic and Migration Studies 39 (3), 373-390.

Walsh, B.A. 1991. Forty good men. The story of the Tanglin Club in the Island of Singapore 1865-1990. Singapore: The Tanglin Club.

Walsh, K. 2006. “'Dad says I'm tied to a shooting star!' Grounding (research on) British expatriate belonging. Area 38 (3): 268-278.

Waters, J.L. 2006. Geographies of cultural capital: Education, international migration and family strategies between Hong Kong and Canada. Transactions of the Institute of British Geographers 31 (2): 179-192.

Williams, A.M. 2007. International labour migration and tacit knowledge transactions: A multi- level perspective. Global Networks 7 (1): 29-50.

Yeoh, B.S.A. 2004. Cosmopolitanism and its exclusions in Singapore. Urban Studies 41 (12): 2431-2445.

Yeoh, B.S.A. 2006. Bifurcated labour: The unequal incorporation of transmigrants in Singapore. Tijdschrift voor Economische en Sociale Geografie 97 (1): 26-37.

Yeoh, B.S.A. and L. M. Khoo. 1998. Home, work and community: Skilled international migration and expatriate women in Singapore. International Migration 36 (2): 159-186. 
Zhang, Y. 2012. Thousand Talent Program brings more pros.

http://www.chinadaily.com.cn/bizchina/2012-04/28/content 15168335.htm Last accessed $30 / 07 / 2014$.

Zulauf, M. 1999. Frontier-free Europe: a study of female migrants in the banking sector. International Journal of Human Resource Management 10 (4): 672-688.

Z/Yen. 2014. The global financial centres index 15 www.zyen.com Last accessed $18 / 02 / 2016$

\section{Short Biographies}

William S. Harvey is Director of the Public Policy Research Cluster, Director of Research and Senior Lecturer in Organisation Studies at the University of Exeter Business School, and an Honorary Senior Lecturer at the University of Sydney. William's research focuses on: the mobility, economic impact and social networks of talented workers; reputation and leadership within professional service firms; practical challenges with fieldwork and interviewing business and political elites. William has published articles in a wide-range of journals in business and management, sociology, geography, migration and industrial relations.

Jonathan V. Beaverstock is Professor of International Management in the School of Economics, Finance and Management at the University of Bristol, UK. A Geographer by training, he has held Chairs in Economic Geography at the University of Nottingham and Loughborough University, UK. He is a world leading expert on highly-skilled international labour migration and work-related mobilities, and the City of London, and has published widely in Business and Management, Geography and Migration and Urban studies. Jonathan is a Fellow of the Academy of Social Sciences and Royal Society of the Arts, Manufacture and Commerce. 
${ }^{1} \mathrm{http} / / / \mathrm{www}$.finaccord.com/press-release 2014 global-expatriates -sizesegmentation-and-forecast-for-the-worldwide-market.htm, accessed $11^{\text {th }}$ June 2015. 